\title{
Design of 50 MW Grid Connected Solar Power Plant
}

\author{
Krunal Hindocha ${ }^{1}$ \\ B.TECH Electrical Engineering \\ Indus University, Ahmedabad \\ Gujarat, India
}

\author{
Dr. Sweta Shah ${ }^{2}$ \\ Asst. Professor \\ Indus University, Ahmedabad \\ Gujarat, India
}

\begin{abstract}
This paper aimed at developing a convectional procedure for the design of large-scale $(50 \mathrm{MW})$ on-grid solar PV systems using the PVSYST Software and AutoCAD. The output of the 50MW grid-connected solar PV system was also simulated using PVsyst software and design of plant layout and Substation to transmit it to $132 \mathrm{Kv}$ Busbar using AutoCAD was done with all standard measures. The project began with a collection of databases of various renewable energy systems components from different producers. In this paper the standard procedure developed was affirm in the design of a 50MW grid connected solar PV. This paper contains the different diagrams and single line diagrams that are required for the design of 50MW grid connect solar power plant.
\end{abstract}

Key words: Solar power plant, power system, Plant Layout, Substation, Substation design, AutoCAD Design, PVsyst performance prediction.

\section{INTRODUCTION}

Now day's conventional sources are rapidly depleting. Moreover, the cost of energy is rising and therefore solar energy is one of the most economical and exploitable renewable sources of energy that can be harnessed for generation of power. There are several advantages of using solar energy like low establishment period, no raw material expenses, non-polluting and renewable form of energy, etc. India has very good conditions for the development of photovoltaic solar power systems due mainly the geographical location and it receives solar radiation almost throughout the year, which amounts to $3000 \mathrm{~h}$ of sunshine. This is equal to more than 5000 trillion $\mathrm{kW} \mathrm{h}$. Almost all parts of India receive 4-7 $\mathrm{kW}$ h of solar radiation per sq meters. The country's solar installed capacity reached 34.045 GW as of 31 January 2020. The Indian government had an initial target of $20 \mathrm{GW}$ capacity for 2022 , which was achieved four years ahead of schedule. In 2015 the target was raised to $100 \mathrm{GW}$ of solar capacity (including $40 \mathrm{GW}$ from rooftop solar) by 2022, targeting an investment of US $\$ 100$ billion. India has established nearly 42 solar parks to make land available to the promoters of solar plants. Photovoltaic modules or panels are made of semiconductors that allow sunlight to be converted directly into electricity. These modules can provide you with a safe, reliable, maintenance-free and environmentally friendly source of power for a very long time. A successful implementation of solar PV system involves knowledge on their operational performance under varying climatic condition and also the adequate knowledge of overall plant layout design and design of substation with an appropriate rating of all the equipment used in the plant.

\subsection{SYSTEM DESIGN AND OBJECTIVE}

A study was conducted for optimise Design of 50MW solar power plant considering all Electrical regulation and standards. The general objective in designing a Solar Power Plant to adequately match the capabilities to the load requirements of the consumer, at a minimum cost of the system to the consumer. In order to accomplish this, the designer will need to know the following types of questions about the system.

(1) Power Requirements, (2)Solar Data Availability, (3)Type and Size of Solar Power Plant Required, (4) Cost of Energy Produced, (5) Solar Power Viability, (6) System Characteristics, (7) System Requirement, (8) Evaluation Criteria, (9) Design Optimization, (10) Economic Viability and (11) Prospects of Cost Reduction.

\section{DESCRIPTION OF SOLAR- PV GRID SYSTEM}

Photovoltaic (PV) refers to the direct conversion of sunlight into electrical energy. PV finds application in varying fields such as Off-grid domestic, Off-grid non-domestic, grid connected distributed PV and grid-connected centralised $\mathrm{PV}$. The proposed $50 \mathrm{Mw} \mathrm{AC}$ is a utility scale grid interactive PV plant.

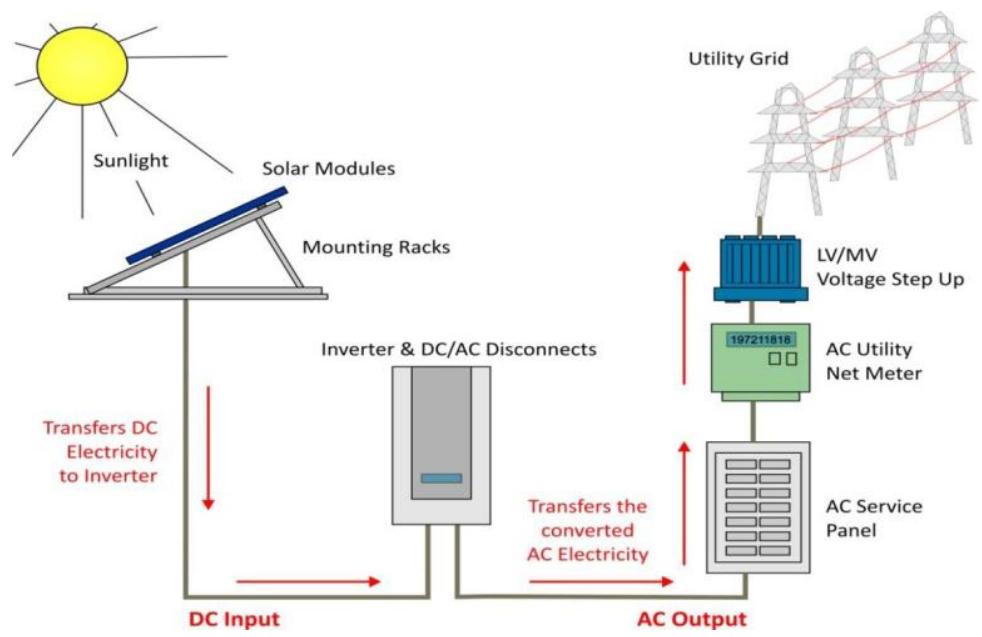

Fig 2.1 Overview of typical Solar PV project 


\section{- Solar PV modules}

\subsection{SOLAR PLANT DC COMPONENTS}

A PV cell is the principal building block of a solar PV plant. Basically, a semi-conductor, PV cells convert sunlight into useful Direct Current (DC) electrical energy. PV cells are small in size and capable of generating only a few Watts (W) of energy. However, PV plants are highly modular (i.e.) modules can be combined together to generate power ranging from a few watts (W) to tens of megawatts (MW). Due to the electrical properties of PV cells, their manufacturing is restricted to a handful of raw materials. Each material has its unique characteristics which impact PV module performance, manufacturing process and cost. PV cells may be based on either wafer (manufactured by cutting wafers from a solid ingot block of material) or "thin film" material (which is deposited onto low-cost substrates).Module Structures allow PV modules to be securely attached to the ground at a fixed tilt angle, or on sun-tracking frames which orient sun. PV cells can further be characterised according to the long-range structure of the semiconductor material used:
3.GENERAL LAYOUT AND DESIGN OF DC PART OF 50MW SOLAR PLANT

- Before Making layout of the Solar power plant, study and analysis is done of the given land.

- $\quad$ study of the proposed site through satellite images to assess the suitability of the site for development of a 50MWAC solar PV plant is done. Also, by the help of PVsyst software all land analysis and generation prediction are done of the given land.

- Thus, by all the analysis and study it was concluded that for Design of 50Mw Solar plant components to be used are:

i) $330 \mathrm{Wp}$ Solar Module

ii) $160 \mathrm{Kw}$ String Inverter (with $45 \%$ overloading)

- Array of Module that is a set of Table is of $2 \times 16$

- Approximately 250 Acers of land will be used to place a 50Mw Solar power plant.

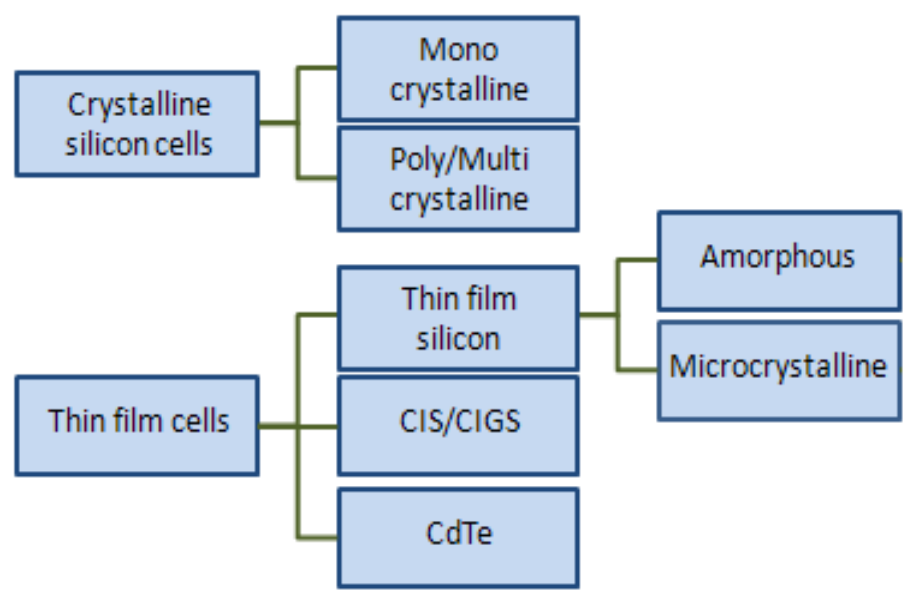

Fig 2.2 Classification of PV Technology

\section{- Inverter}

Inverters are solid state electronic devices. They convert DC electricity generated by the PV modules into AC electricity. Inverters can also perform a variety of functions to maximise the output of the plant. These range from optimising the voltage across the strings and monitoring string performance to logging data, and providing protection and isolation in case of irregularities in the grid or with the PV modules.

There are two broad classes of inverters:

\section{i) String Inverters ii) Central Inverter}

Considering all the losses in inverter from DC to AC, in cables and other transmission losses Solar plant will be designed with $45 \%$ overloading of inverter 
As mentioned above per Module is of $330 \mathrm{wp}$, and each table have such $\mathbf{3 2}$ modules so per Table capacity $=\mathbf{1 0 . 5 6 K}$

$\checkmark$ For $50 \mathrm{Mw}$ plant, one Block of 858 tables having capacity of $6.25 \mathrm{Mw}$ is selected. So, total such 8 blocks are required to reach $50 \mathrm{Mw} \mathrm{AC}$

$\checkmark$ As mentioned above $160 \mathrm{Kw}$ inverter is used in this $50 \mathrm{Mw}$ plant. But overloading of $45 \%$ is considered so per Inverter capacity would be $160 * 1.45=232 \mathrm{DC}$

$\checkmark \quad$ Number of inverters for $50 \mathrm{Mw}$ plant $=\mathbf{3 1 2}$ units

$\checkmark$ Total inverter capacity of plant: $312 * 232=\mathbf{7 2 3 8 4 M w}$ DC

$\checkmark$ AS per table is of $10.56 \mathrm{Mw}$, total number of tables in 50Mw plant will be $\mathbf{6 8 6 4}$ units

- Layout of the tables on the given land is done with a standard measurement. Such that shadows are avoided of the surrounding tables or other structure.

Horizontal distance between 2 tables $=\mathbf{0 . 1 0 0 m}$

Vertical distance between 2 table $=\mathbf{3 . 5 8 6 0} \mathrm{m}$

Pitch $=7.500 \mathrm{~m}$

\subsection{STUDY OF ONE BLOCK OF 6.25 MW:}

Each block consists of total 858 tables and 39 inverters. So, for per inverter 22 tables are connected. The grouping of tables is done 22 table in one group connected to one inverter. Total such 8 blocks are made for $50 \mathrm{Mw}$ plant.

Per block - 6.25Mw

Inverter - $160 \mathrm{Kw}(45 \%$ overloading $)$

Therefore, $6.25 / 0.160=39$ Number of inverters per block

Per Inverter capacity - $\mathbf{2 2}$ tables

So, for total 39 inverters in one block and total tables in one block $\mathbf{- 8 5 8}$ units

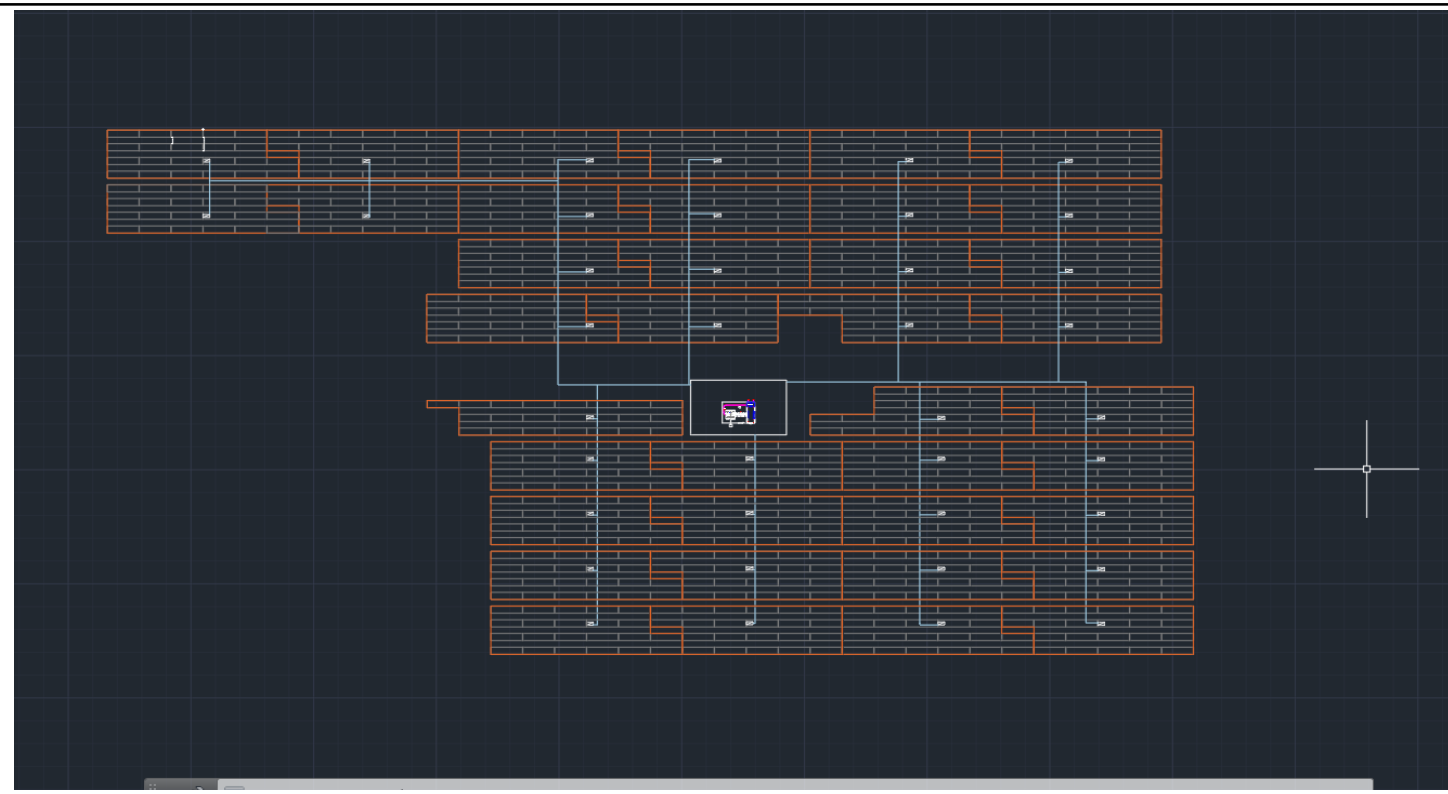

Fig 3.1 Single Block layout 


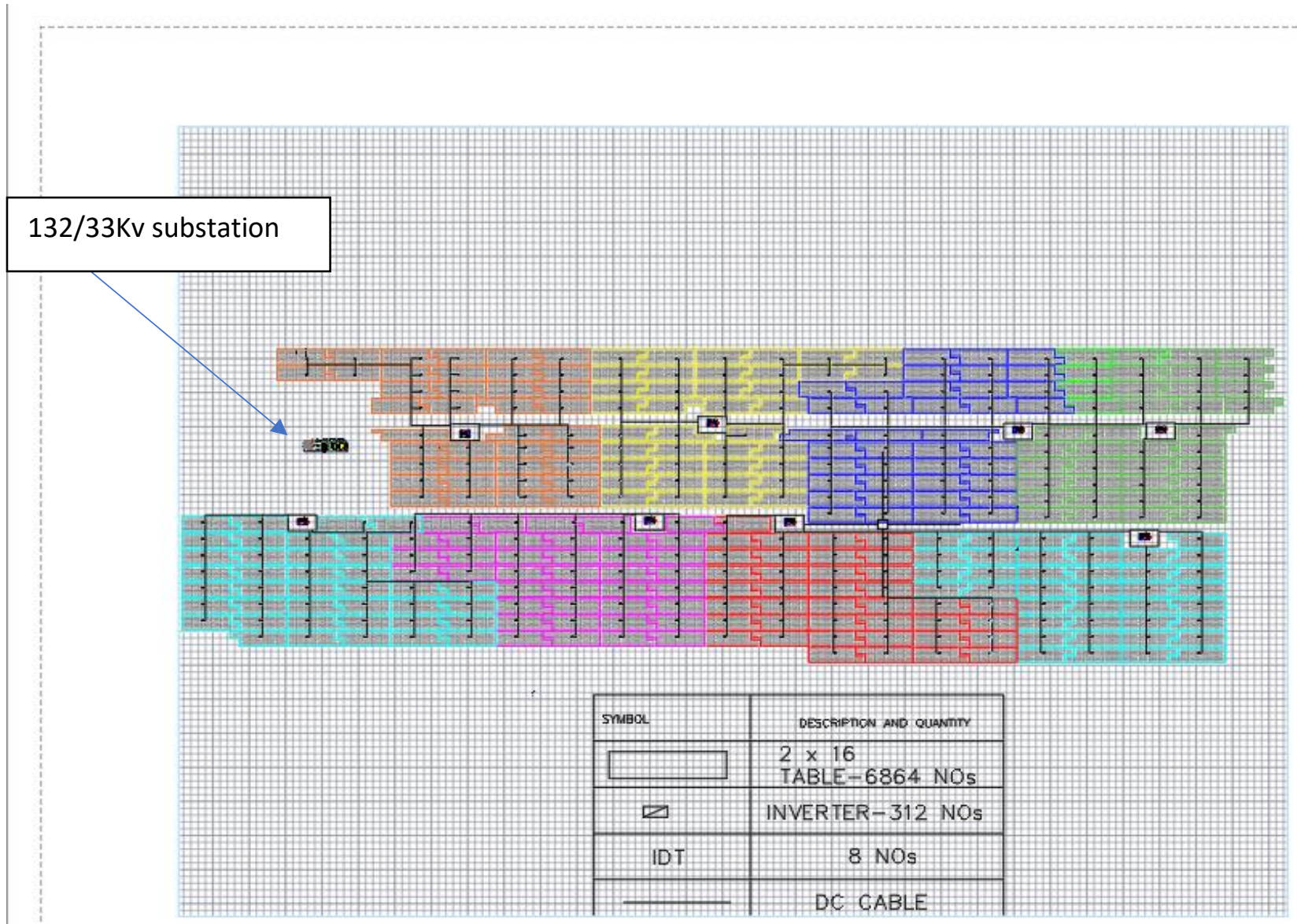

Fig 3.2 50MW Solar plant Block layout

\begin{tabular}{|l|l|}
\hline \multicolumn{1}{|c|}{ BLOCK } & COLOR IDENTIFICATION \\
\hline BLOCK 1 & ORANGE \\
\hline BLOCK 2 & YELLOW \\
\hline BLOCK 3 & BLUE \\
\hline BLOCK 4 & GREEN \\
\hline BLOCK 5 & LIGHT BLUE \\
\hline BLOCK 6 & PURPLE \\
\hline BLOCK 7 & RED \\
\hline BLOCK 8 & LIGHT BLUE \\
\hline
\end{tabular}

\begin{tabular}{|l|l|}
\hline EQUIPMENTS & QUANTITY \\
\hline TABLES & 6864 UNITS \\
\hline INVERTERS & 312 UNITS \\
\hline IDT STATION & 8 \\
\hline BLOCKS & 8 \\
\hline
\end{tabular}


- Hence, by standard dimension and land allocated all the tables, Inverter and IDT (Inverter Duty Transformer) are place. Now DC cables are to be placed from every inverter to IDT in an optimise way in which minimum cable are stretched so as to set minimum DC cable losses and minimum digging work.

- In Inverter DC power from solar generation is inverted to AC power which is collected and pass to the Inverter Duty Transformer. By the help of LT cable power from inverter to IDT is transferred where power is stepped up by the transformer. After step up using HT cable it is passed to $33 \mathrm{kv}$ switchgear.

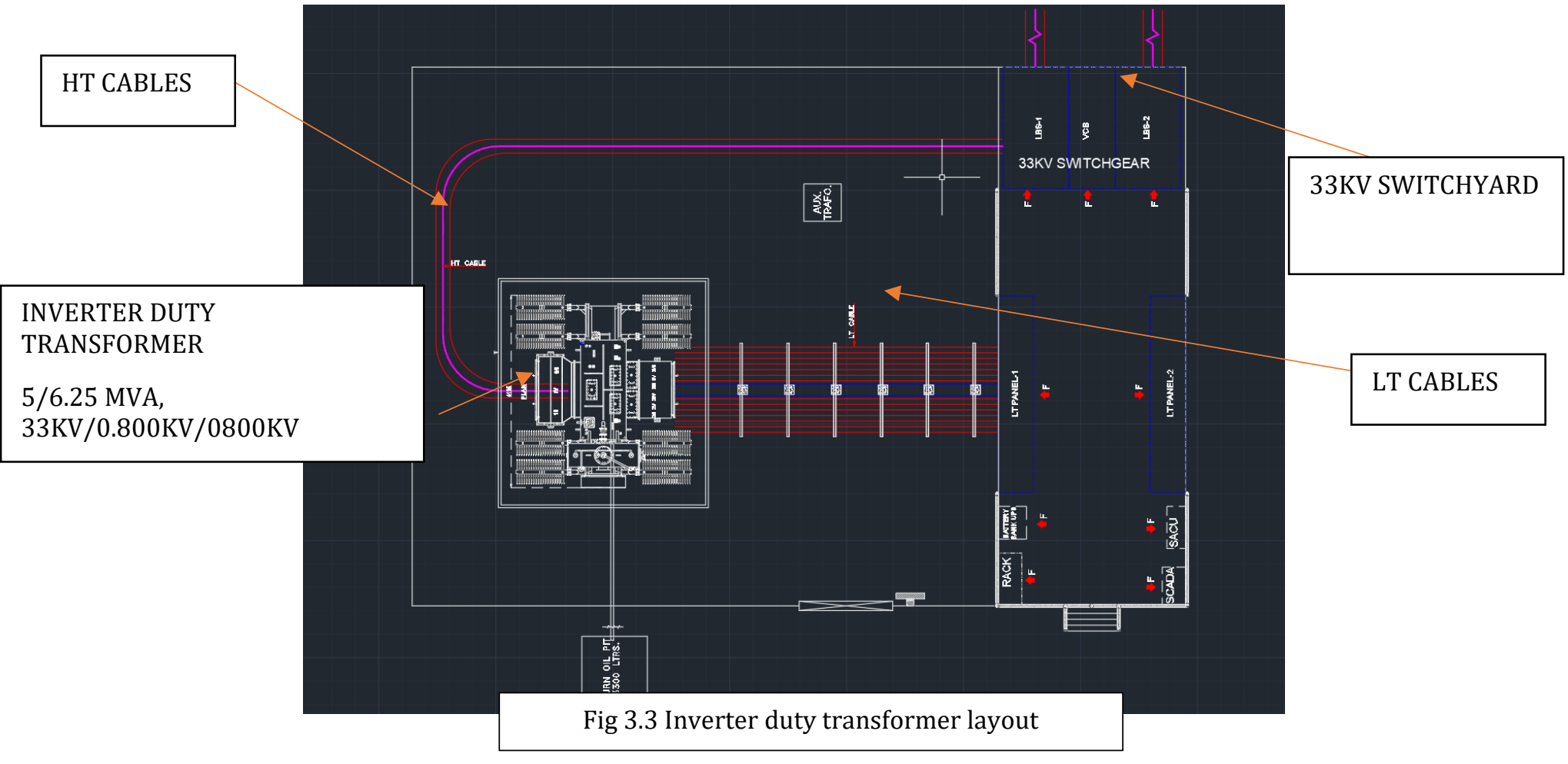

\subsection{STRING INVERTER CONNECTION}

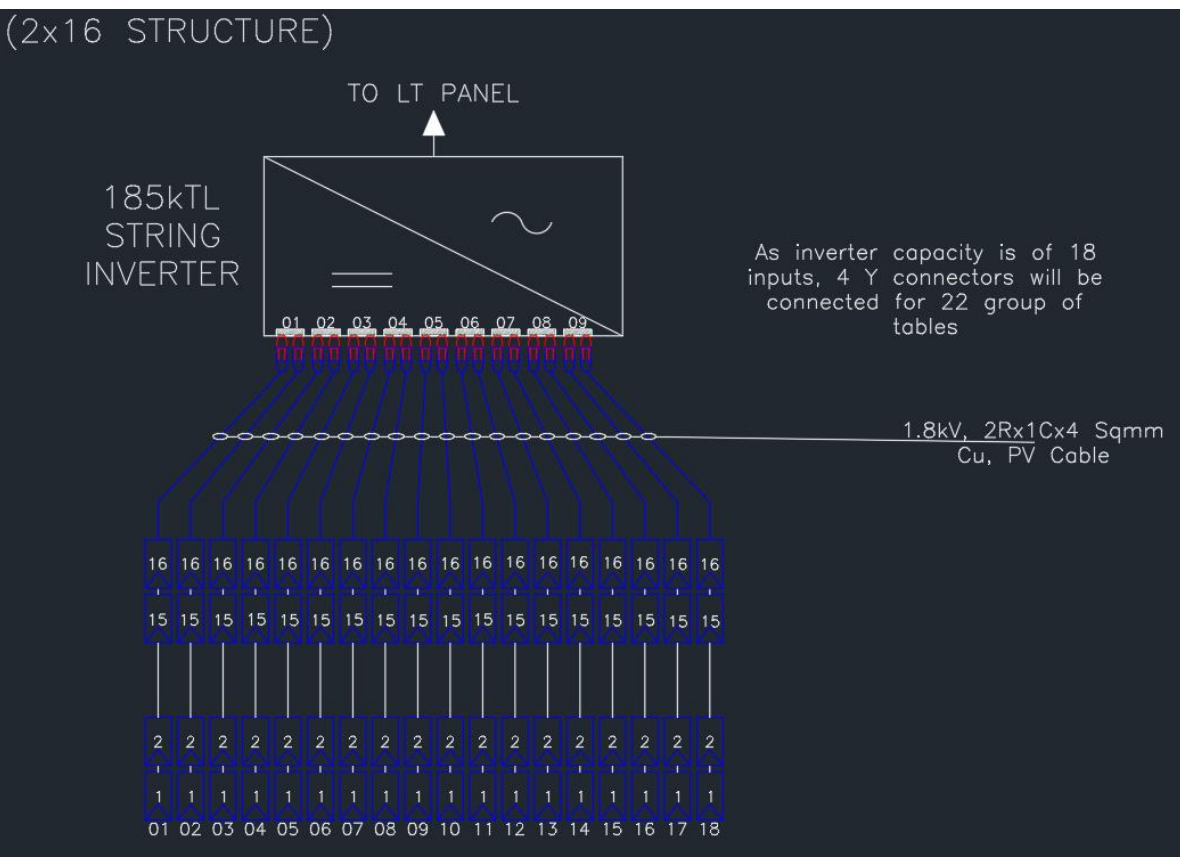

For $160 \mathrm{kw}$ inverter, Huawei $185 \mathrm{kTL}$ is selected. (Datasheet of this inverter is provided at the end) As input capacity of this inverter is $18,4 \mathrm{Y}$ connectors will be used to connect the connection of 22 tables with an Inverter.

Fig 3.4 String Inverter Connection diagram 


\subsection{INVERTER TO IDT CONNECTION DIAGRAM}

50MW

TYPICAL 6.25MW BLOCK

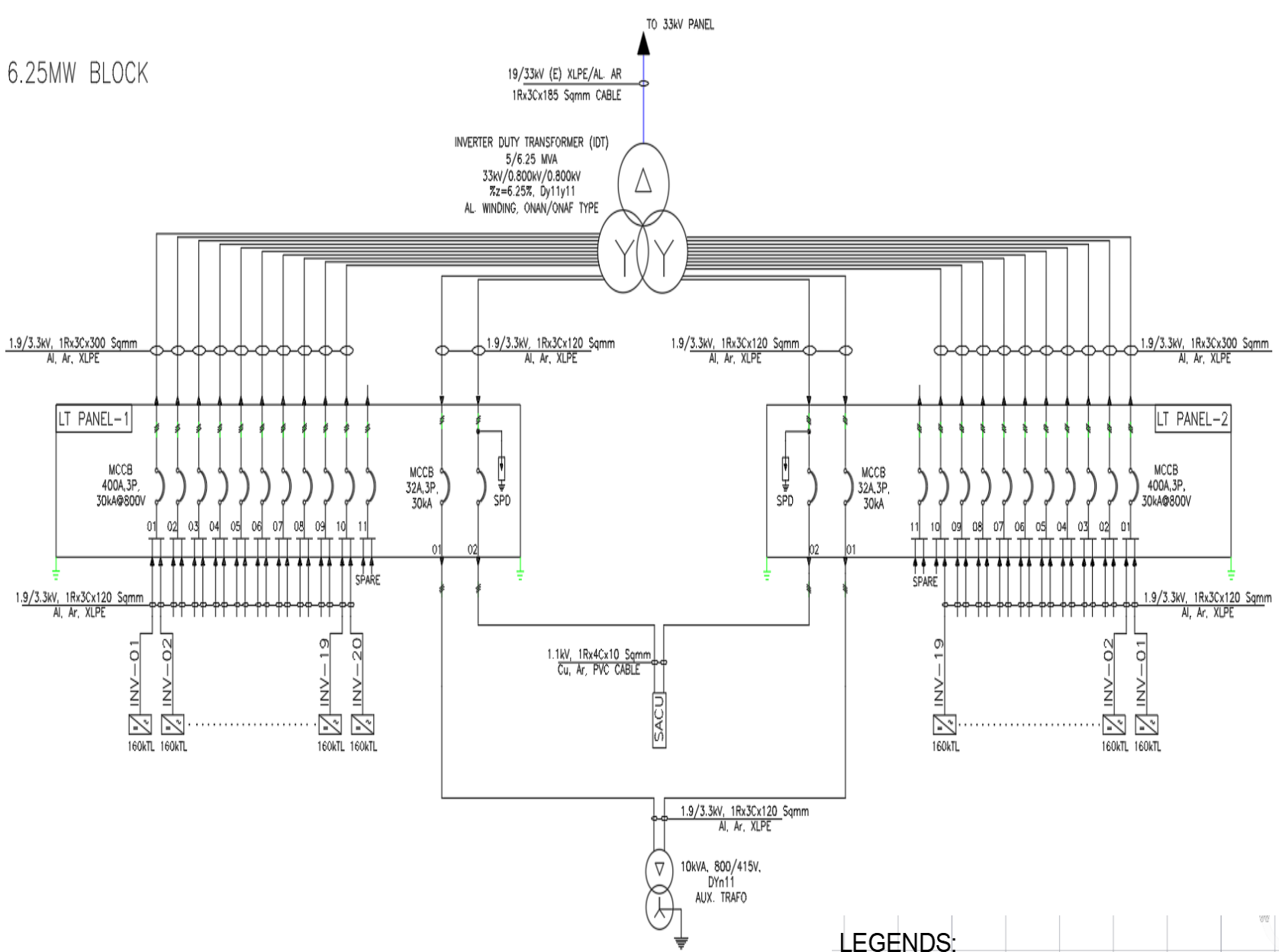

Fig 3.5 String inverter to IDT connection diagram

LEGENDS:

Fig 3.5 String inverter to IDT connection diagram

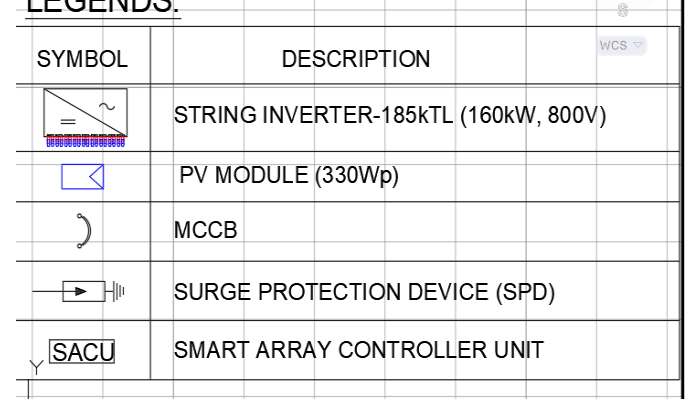

\begin{tabular}{|l|l|}
\hline \multicolumn{1}{|c|}{ Equipment } & \multicolumn{1}{c|}{ Ratings and Type } \\
\hline Inverter Duty Transformer (IDT) & $\begin{array}{l}5 / 6.25 \mathrm{MVA} \\
33 \mathrm{kv} / 0.800 \mathrm{kv} / 0800 \mathrm{kv} \\
\text { Dy11y11 ONAN /ONAF type }\end{array}$ \\
\hline MCCB & 400A ,3P ,30kA@800v AND 32A,3P,30kA \\
\hline Auxiliary Transformer & $10 \mathrm{kVA}, 800 / 415 \mathrm{~V}, \mathrm{DYn} 11$ \\
\hline Cable & $1.9 / 3.3 \mathrm{kv}, 1 \mathrm{Rx} 3 \mathrm{Cx} 120 \mathrm{sq} \mathrm{mm}$ \\
\hline & $1.9 / 3.3 \mathrm{kv}, 1 \mathrm{Rx} 3 \mathrm{Cx} 300 \mathrm{sq} \mathrm{mm}$ \\
\hline & $19 / 33 \mathrm{kV}, 1 \mathrm{Rx} 3 \mathrm{C} 185 \mathrm{sq} \mathrm{mm}$ \\
\hline
\end{tabular}




\section{DESIGN OF AC PART OF 50MW SOLAR POWER PLANT}

Up till now, DC portion of plant was discussed that is up to IDT. After inverting the power from DC to AC power it is to be step up so as to meet the voltage level and frequency of the line grid where the generated power is to be transferred. In AC portion of plant voltage level is quite higher so lots of protecting systems are required. In the power plant most important and costliest equipment is transformer which is to be protected first.

Following are the electrical equipment used in the substation for protecting and metering purpose:

$\begin{aligned} \text { i. } & \text { MV Switchgear } \\ \text { ii. } & \text { Bus-Bar Schemes } \\ \text { iii. } & \text { Switchyard } \\ \text { iv. } & \text { Circuit Breakers } \\ \text { v. } & \text { Isolators } \\ \text { vi. } & \text { Instrument Transformers } \\ \text { vii. } & \text { Surge Arresters } \\ \text { viii. } & \text { Insulators } \\ \text { ix. } & \text { Metering } \\ \text { x. } & \text { Earthing System } \\ \text { xi. } & \text { Lightning Protection }\end{aligned}$

\section{SINGLE LINE DIAGRAM (SLD)}

\subsection{SLD OF 33KV PANEL}

Power in IDT after step up to $33 \mathrm{Kv}$ it is passed to $33 \mathrm{Kv}$ switchgear panel. Here power is pass through the protecting system before transferring to $132 \mathrm{kv}$ Substation. Below SLD shows the flow of power in $33 \mathrm{kv}$ panel.

In the given panel surge arrester is connected to protect from any short period surge power. Next comes CT for metering and protection. Then circuit breaker is placed to break the circuit in case of fault. Further on PT is placed to measuring and protection. From this power is transferred to main $33 \mathrm{Kv}$ panel.

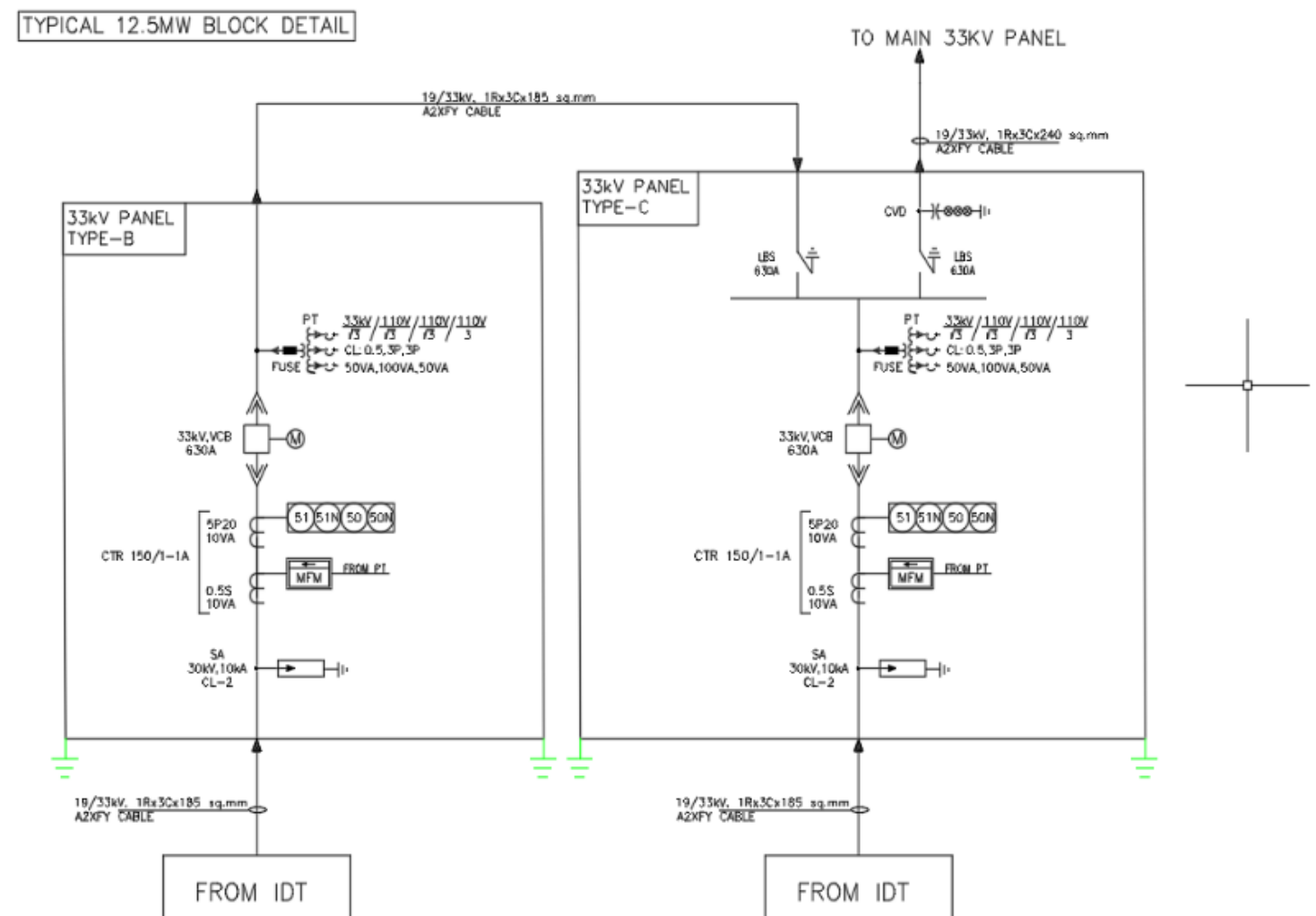

Fig 5.1 33Kv panel Single line diagram 


\subsection{GENERAL SUBSTATION SLD}

As discussed above, substation is equipped with the rated and fast responding protection equipment to make the smooth flow of power without any breakdown due to faults.

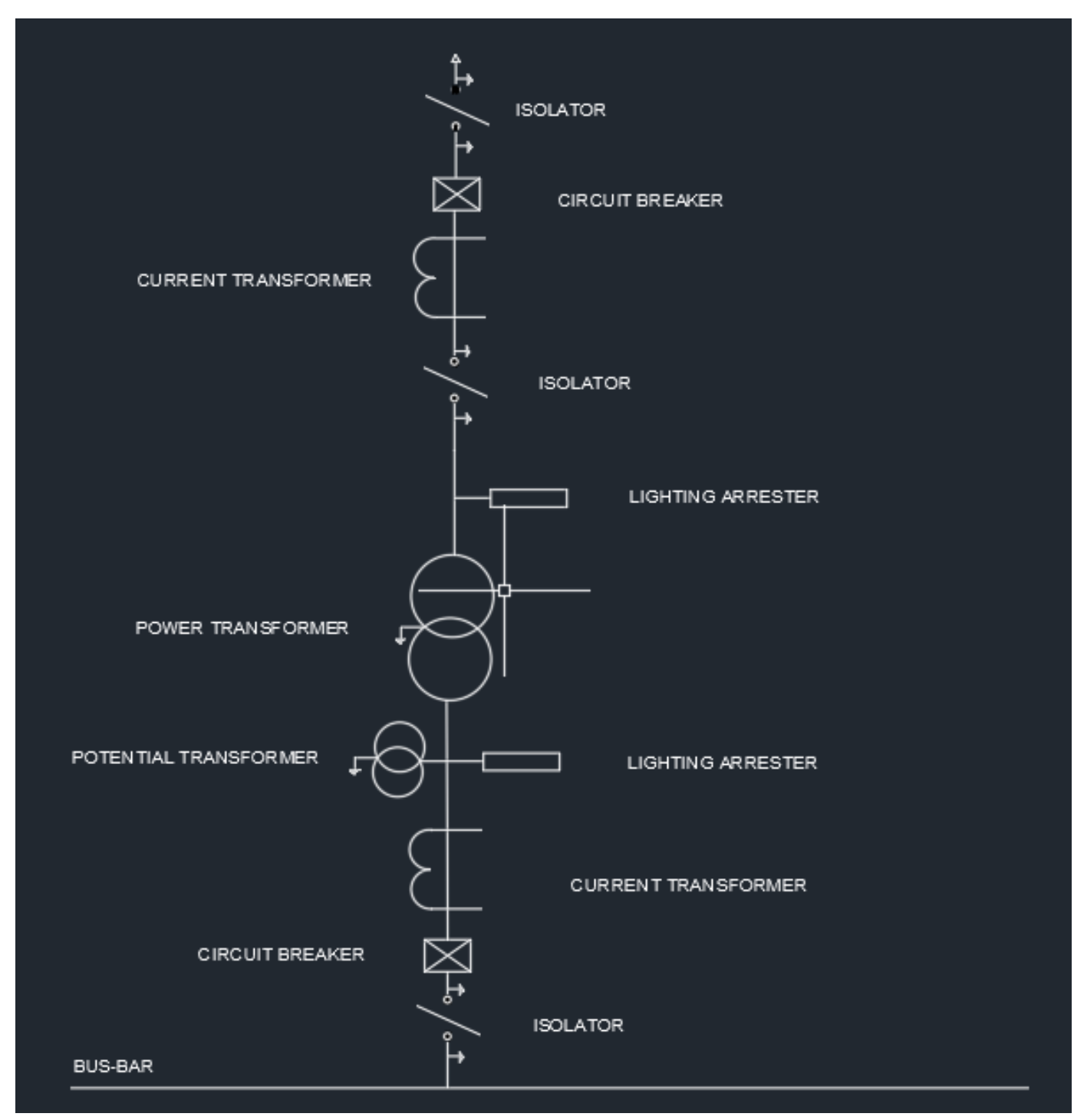

Fig 5.2 Substation general Single line Diagram 


\section{$5.3132 \mathrm{KV} / 33 \mathrm{KV}$ POOLING SUBSTATION}

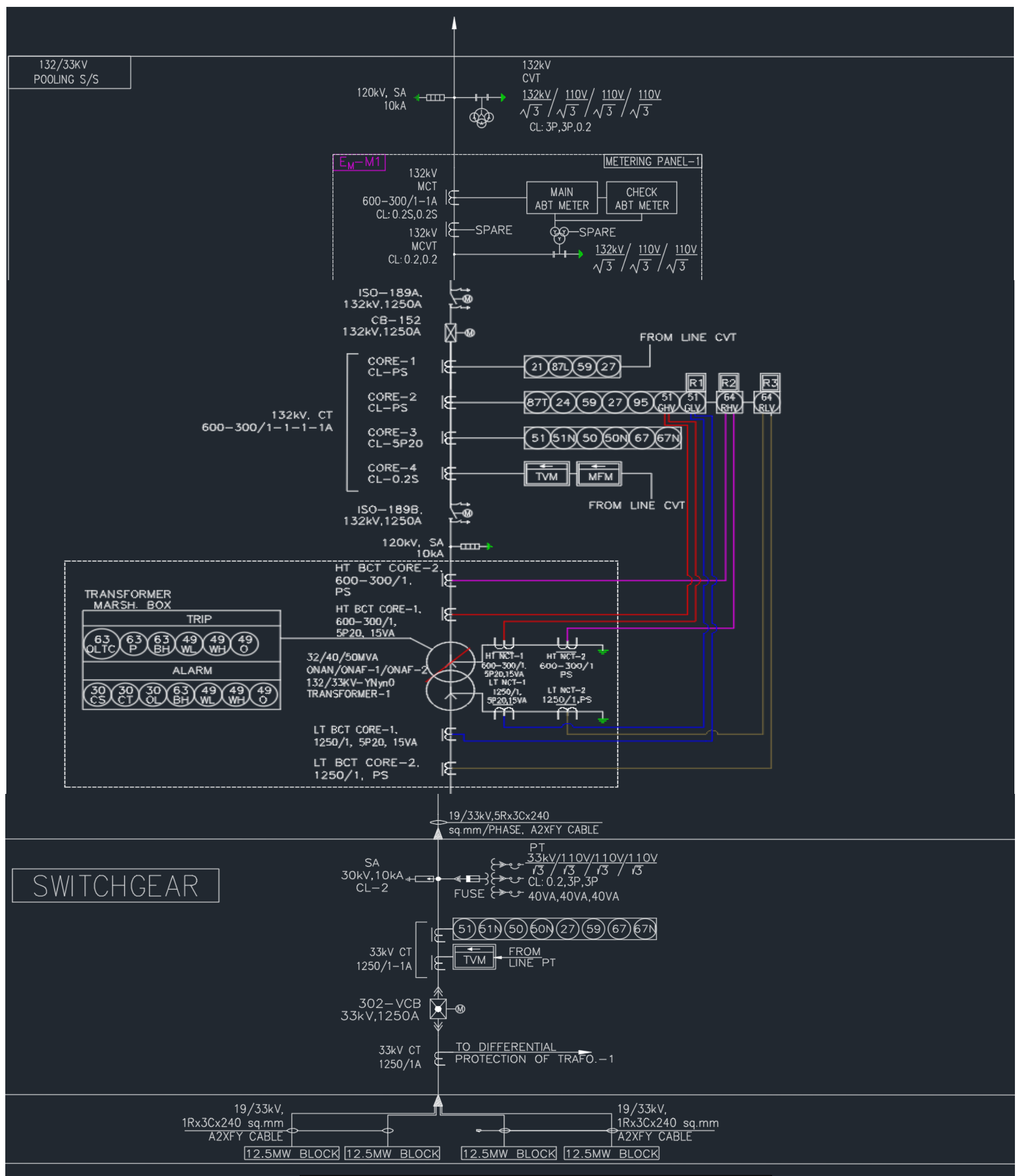

Fig $5.2132 \mathrm{Kv} / 33 \mathrm{Kv}$ pooling substation SLD with Metering M1 


\subsection{KV SUBSTATION SLD}

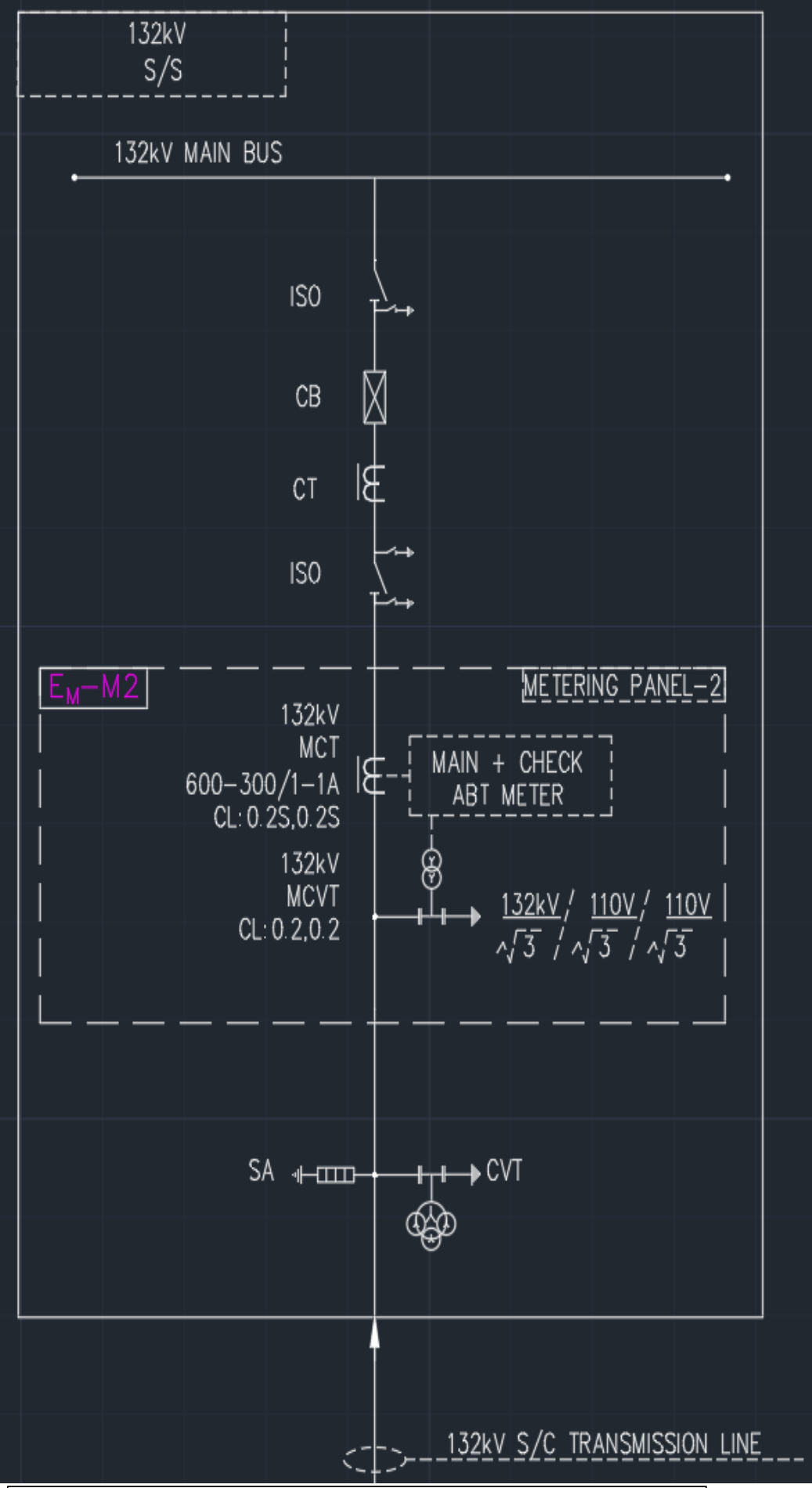

\begin{tabular}{|c|c|}
\hline straba & ABERMATION \\
\hline 8 & POWER TRANSFORMER \\
\hline \& & AUXILIARY TRANSFORMER \\
\hline 宸- 0 & SF6 CIRCUIT BREAKER \\
\hline$\hat{\mathbb{V}}-\infty$ & VACUUM CIRCUIT BREAKEF \\
\hline$\phi$ & CURRENT TRANSFORMER \\
\hline 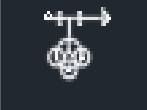 & $\begin{array}{l}\text { CAPACITOR VOLTAGE } \\
\text { TRANSFORMER }\end{array}$ \\
\hline $1 / 0$ & ISOLATOR \\
\hline$\rightarrow$ & EARTH SWITCH \\
\hline$-\mathrm{m}+$ & SURGE ARRESTER \\
\hline & LOAD BREAK SWTCH \\
\hline & FUSE \\
\hline
\end{tabular}

ABBRIVIATION

\begin{tabular}{|l|l|}
\hline BCT & BUSHING CURRENT TRANSFORMER \\
\hline NCT & NEUTRAL CURRENT TRANSFORMER \\
\hline ABT & AVAIBILITY BASED TERIFF \\
\hline MFM & MULTIFUNCTION METER \\
\hline TVM & TRIVECTOR METER \\
\hline
\end{tabular}

Fig 5.4 Symbols and Abbreviations

Fig 5.3 132Kv substation SLD with Metering M2

M1 = Energy values in ABT Meter at $132 \mathrm{kv}$ plant end. M2 = Energy values in ABT Meter at $132 \mathrm{kv}$ Remote end. Total Losses $(\mathrm{L})=\mathrm{M} 1-\mathrm{M} 2$

\section{SIMULATION USING PV SYST SIMULATION} SOFTWARE

Data obtained for irradiation on collector plane, PV module and inverter specifications and plant configuration are input into the PV modelling software PV Syst to calculate DC energy generated from the modules in hourly time steps throughout the year. This direct current is converted to AC in the inverter. A number of losses occur during the process 
of converting irradiated solar energy into AC electricity fed into the grid. The losses may be described as a yield loss factor. They are calculated within the PV modelling software and calculated from the cable dimensions.

\subsection{MONTH-WISE ENERGY YIELD PREDICTION} (P50)

Table: Month-wise breakup of P50 energy yield

\begin{tabular}{|l|l|}
\hline Month & $\begin{array}{l}\mathbf{5 0} \text { MW } \\
\text { Project Total MWh } \\
\text { Generation }\end{array}$ \\
\hline January & 6,872 \\
\hline February & 9,142 \\
\hline March & 11,923 \\
\hline April & 11,927 \\
\hline May & 11,624 \\
\hline June & 9,510 \\
\hline July & 8,064 \\
\hline August & 9,182 \\
\hline September & 9,426 \\
\hline October & 10,030 \\
\hline November & 8,387 \\
\hline December & 7,440 \\
\hline $\begin{array}{l}\text { Total Estimated MWh } \\
\text { Generation }\end{array}$ & $1,13,527$ \\
\hline
\end{tabular}

\subsection{GENERATION AND CAPACITY UTILISATION} FACTOR (CUF)

The Capacity Utilization Factor (CUF) also known as Plant Load Factor (PLF) of a PV power plant (usually expressed as a percentage) is the ratio of the actual output over the period of a year and its output if it had operated at nominal power the entire year, as described in the formula below.

CUF $(A C)=$ Energy Generated per annum $(\mathrm{MWh}) /(8760$ $x$ Installed AC Capacity in MW)

The Year 1 Generation and aggregate CUF (AC) on cumulative project capacity is as below:

\begin{tabular}{|l|l|}
\hline $\begin{array}{l}\text { Year } 1 \text { Generation and } \\
\text { CUF }\end{array}$ & $\begin{array}{l}\mathbf{5 0} \text { MW } \\
\text { Project Total }\end{array}$ \\
\hline P90 Generation & $107,596 \mathrm{MWh}$ \\
\hline P90 \% CUF (AC) & $24.56 \%$ \\
\hline P75 Generation & $102,246 \mathrm{MWh}$ \\
\hline P75 \% CUF (AC) & $23.34 \%$ \\
\hline P50 Generation & $113,527 \mathrm{MWh}$ \\
\hline P50 \% CUF (AC) & $25.92 \%$ \\
\hline
\end{tabular}

\subsection{PERFORMANCE RATIO}

The quality of a PV power plant may be described by its Performance Ratio (PR). Usually expressed as a percentage, can be used to compare PV systems independent of size and solar resource.

The PR is expressed as:

\% PR $=($ Energy generated per annum $\times 100 \%) /$ (Installed Capacity x Plane of Array Irradiation)

By normalising with respect to irradiation at Standard Temperature Conditions (STC), the PR quantifies the overall effect of losses on the rated output and allows a comparison between PV plants.

\begin{tabular}{|l|l|}
\hline $\begin{array}{l}\text { Expected Performance } \\
\text { Ratio (PR) }\end{array}$ & $\begin{array}{l}\mathbf{5 0} \mathbf{M W} \\
\text { Project Total }\end{array}$ \\
\hline \% PR of Year 1 & $80.70 \%$ \\
\hline
\end{tabular}




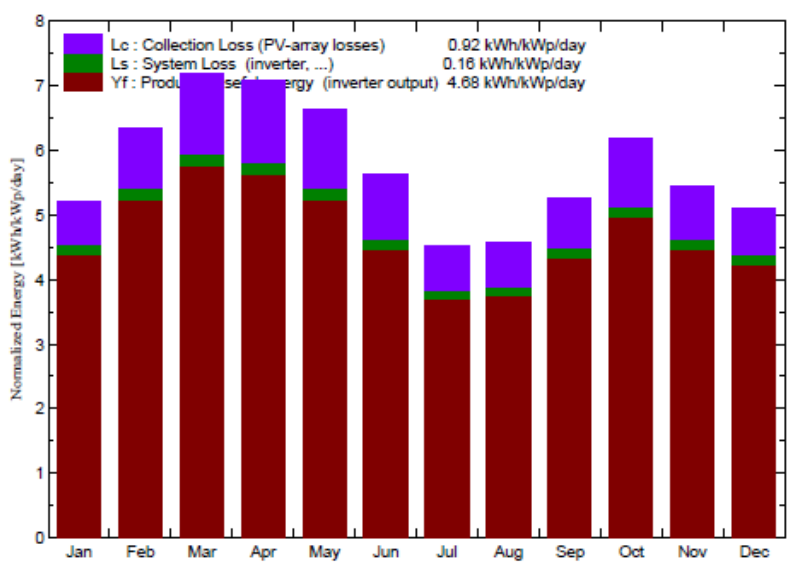

Fig 6.1 Normalized production per installed kwh

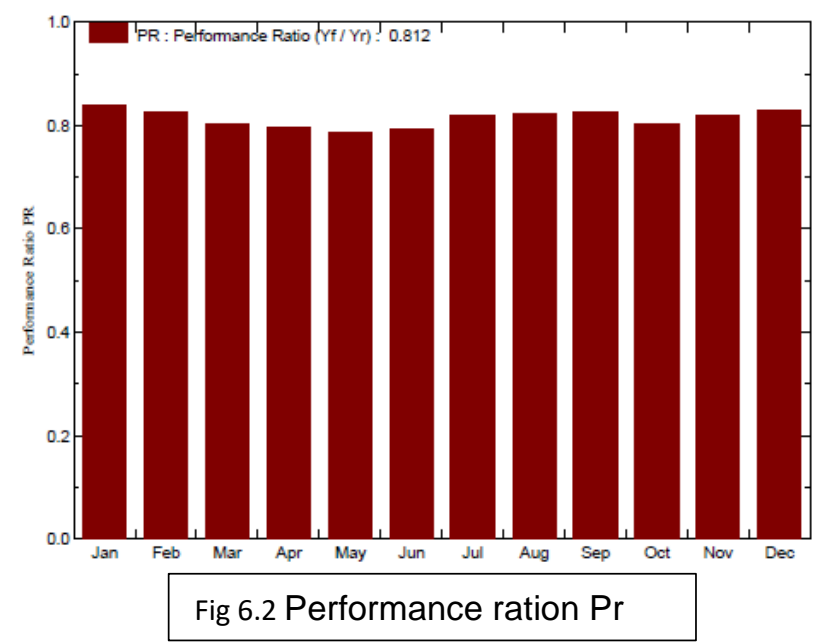

\section{CONCLUSION}

Hence a study was concluded for 50MW on grid Solar power plant. Concluding the overview of solar plant with all the necessary components of DC as well as for AC. With all this analysis a design of 50MW on grid solar power plant was done using AutoCAD. Designs included the plant layout and all the electrical diagrams with electrical standard measures. Also, using PVsyst software plant efficiency and generation prediction was calculated which comes out to be $80.70 \%$ for 1 year.

Also, after studying whole plant and its procedure to develop it, some of the research study was done along with this design which can be helpful in future to increase the efficiency of any solar plant. Firstly, using the Black silicon in manufacturing of PV module will increase the module efficiency as black silicon trap and hold maximum solar radiations. And other idea can be implemented in future of Agro Solar plant which include the agriculture of herbs on a cultivated land also can fix solar plant both simultaneously

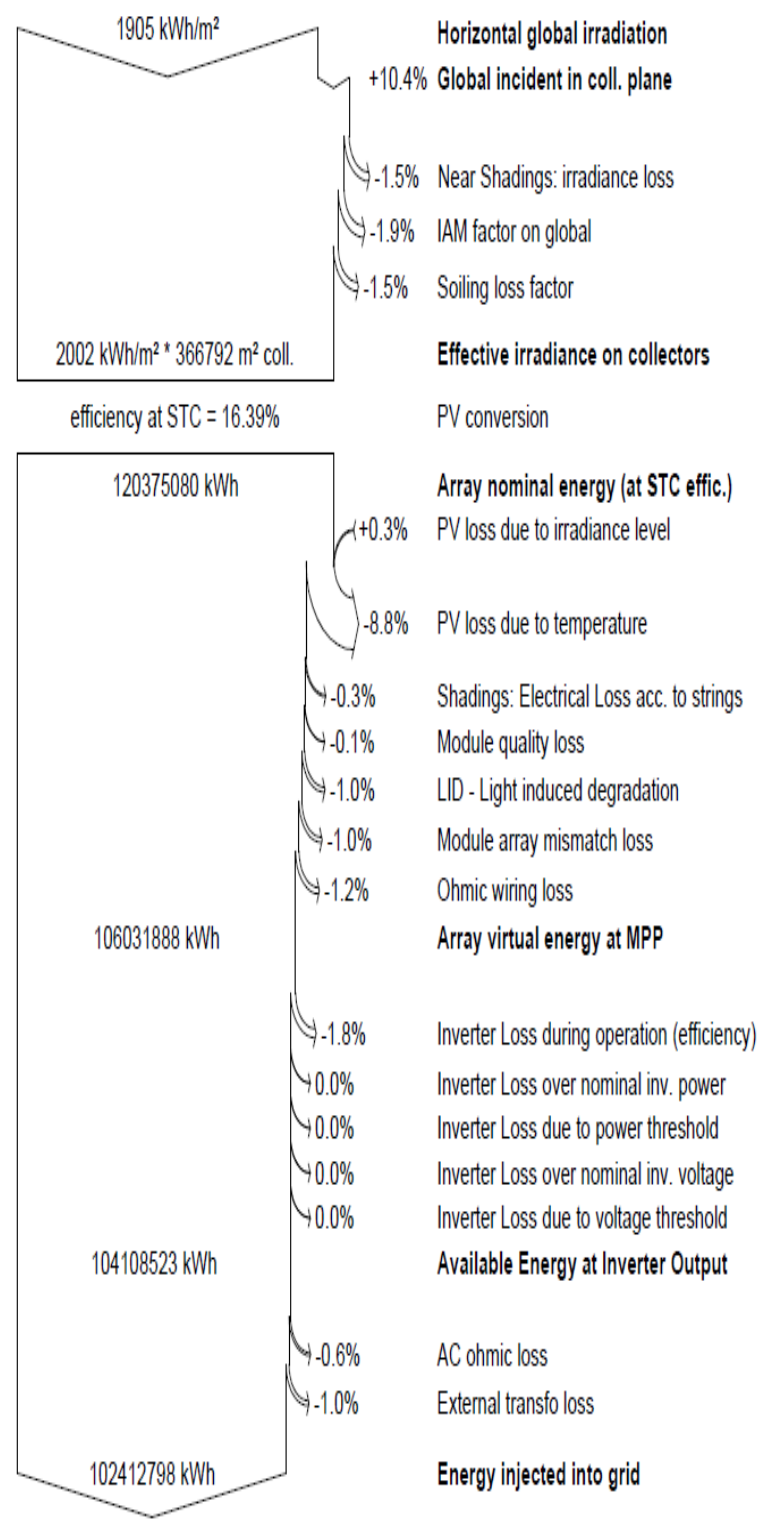

which is said to be Agrosolar plant. Also updating a technology in software used in designing the plant which can reduce man-work and software can calculate and design its own plant design by knowing land coordinates and plant capacity required.

\section{REFERENCES}

[1] https://en.wikipedia.org/wiki/Solar_power_in_India

[2] Vasanth Kumar, Dr. S. Kumarappa, Dr. H. Naganagouda Design and Development of 5MW Solar PV Grid Connected Power Plant Using PVsyst.

[3] Performance evaluation of $10 \mathrm{MW}$ grid connected solar photovoltaic power plant in India (B. Shiva Kumar, K. Sudhakar)

[4] Elhodeiby, A.S., Metwally, H.M.B., Farahat, M.A., 2011. Performance analysis of $3.6 \mathrm{~kW}$ Rooftop grid connected photovoltaic system Egypt. In: InternationalConference on Energy Systems and Technologies, Cairo, Egypt, CEST 2011,11-14 March. Goura, R., 2015. Analyzing the on-field performance of a 1-641 megawatt-grid -tied PV system in South India. Int. J. Sustainable Energy 34, 1-9.

[5] IEEE Standard Definitions of Terms for Solar Cells, 1999. 
[6] H.Mithavachan,Anandhi Gokhale and J.Srinivasan "performance assessment of 3MW scale grid connected solar plant at kolar,Karnataka."August 2011

[7] Design on AutoCAD

[8] Output performance on PVsyst

\section{TECHNICAL DATASHEET 9.1 SOLAR MODULE DATASHEET}

\begin{tabular}{|l|l|}
\hline Characteristics & Value \\
\hline Type & Polycrystalline \\
\hline Nominal Power (PMPP) & $330 \mathrm{Wp}$ \\
\hline $\begin{array}{l}\text { Voltage at Pmax } \\
\text { (VMPP) }\end{array}$ & $37.71 \mathrm{~V}$ \\
\hline Current at PMax (IMPP) & $8.75 \mathrm{~A}$ \\
\hline $\begin{array}{l}\text { Open Circuit Voltage } \\
\text { (VOC) }\end{array}$ & $46.40 \mathrm{~V}$ \\
\hline $\begin{array}{l}\text { Short Circuit Current } \\
\text { (ISC) }\end{array}$ & $9.24 \mathrm{~A}$ \\
\hline Module Efficiency & $16.8 \%$ \\
\hline Temperature range & $40^{\circ} \mathrm{C}$ to $+85^{\circ} \mathrm{C}$ \\
\hline $\begin{array}{l}\text { Dimensions } \\
\text { Module Area } \\
\text { Weight }\end{array}$ & $1,956 \mathrm{~mm} \times 992 \mathrm{~mm} \mathrm{x} \mathrm{40mm}$ \\
\hline
\end{tabular}

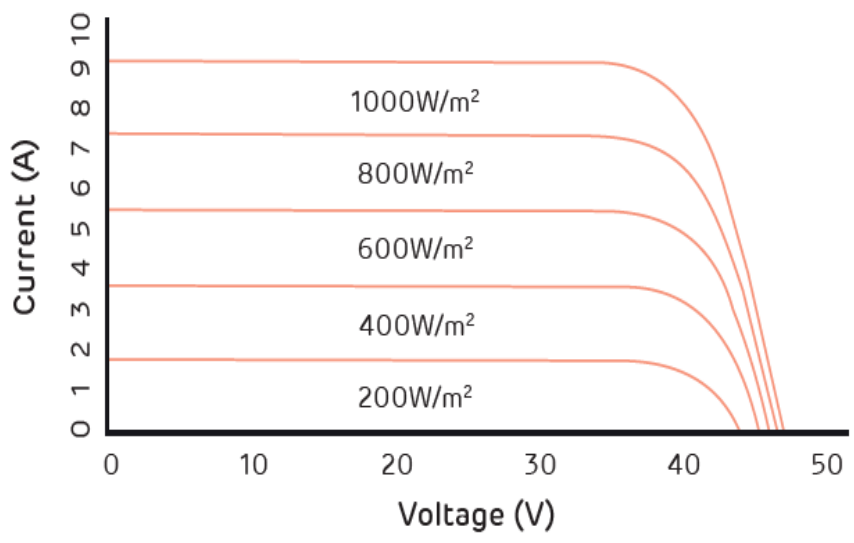

\subsection{STRING INVERTER DATASHEET}

\begin{tabular}{|l|l|}
\hline Type & String \\
\hline Max. Input Voltage & $1500 \mathrm{~V}$ \\
\hline Max. current per MPPT & $26 \mathrm{~A}$ \\
\hline Max. Short circuit current per MPPT & $40 \mathrm{~A}$ \\
\hline Start voltage & $550 \mathrm{~V}$ \\
\hline MPPT operating voltage range & $500 \mathrm{~V}-1500 \mathrm{~V}$ \\
\hline Nominal input voltage & $1080 \mathrm{~V}$ \\
\hline Number of inputs & 18 \\
\hline Number of MPP trackers & 9 \\
\hline Nominal Ac Active power & $175 \mathrm{kw} @ .40^{\circ} \mathrm{C}$ \\
& $160 \mathrm{kw} @ 50^{\circ} \mathrm{C}$ \\
\hline Max. AC Active power & $185 \mathrm{kw}$ \\
\hline Nominal Output voltage & $800 \mathrm{~V}$ \\
\hline Nominal output current & $126.3 @ .40^{\circ} \mathrm{C}$ \\
& $115.5 @ 50^{\circ} \mathrm{C}$ \\
\hline Max. Output current & $134.9 \mathrm{~A}$ \\
\hline Max. total Harmonic Distortion & $<3 \%$ \\
\hline Dimension & $1035 \times 700 \times 365 \mathrm{~mm}$ \\
\hline Weight & $84 \mathrm{~kg}$ \\
\hline Operating Temp. Range & $-25^{\circ} \mathrm{C} \sim 60^{\circ} \mathrm{C}$ \\
\hline
\end{tabular}

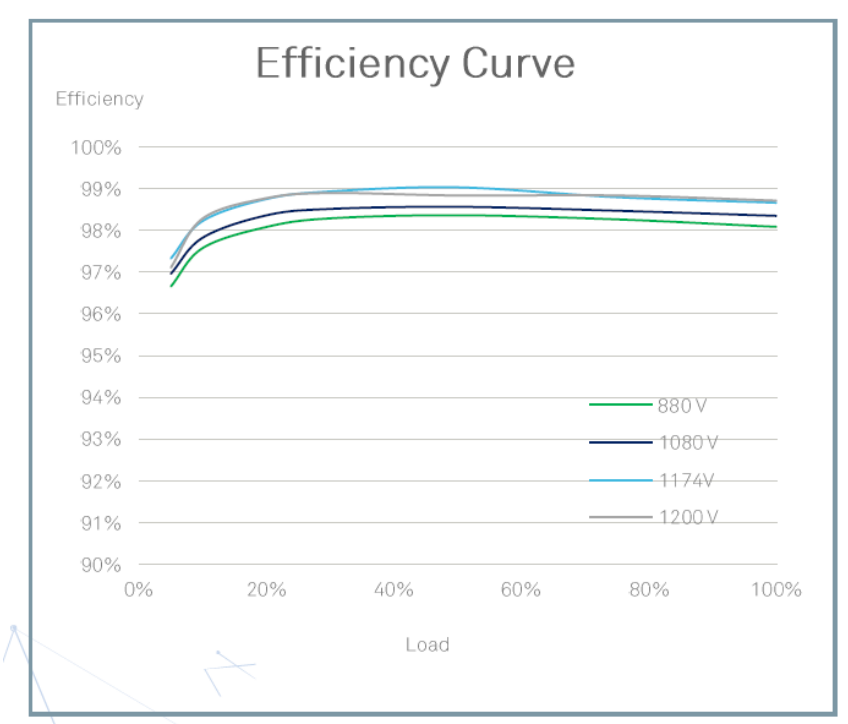

